\title{
MANAGEMENT OF MAIN THREATS DURING REALISATION OF BIG SPORT EVENTS
}

\author{
Agnieszka Ulfik ${ }^{1}$ \\ Stefan Nowak ${ }^{2}$
}

ABSTRACT: Organizing major sporting events is inextricably linked with reducing the risks. These risks may be caused by the uncontrolled behavior of the crowd, different type of accidents or hardware failure as well as terrorist threats. Other main factors creating dangers currently can be included: problems with safety of filling structure with audience, control against carrying in dangerous objects, fans reactions which can change into aggressive behaviours. Correct designing of all elements of sport spectacle and their efficient realization can contribute that events will take place without disturbance, additional stress and that dangerous situations will be easy to take under control. Management of sport structures on which sport and cultural events with mass character can take place, brings different type of dangers and problems of organizational nature. During organization sport spectacle, its organizers are responsible for order of lasting event, where together with host of object and also cooperating services, secures feeling of safety for participants. The led investigation on terrain of Polish stadiums, aim to elaborate procedures which will become practically used during European Football Championship, which will be played in Poland and Ukraine in 2012.

Key words: management, threats, organization of sport events

JEL code: $M 00$

Introduction: Characteristic of structures on which are realised league and international games

Sport structures able to realisation of events with international character have to meet specific requirements, which together with increasing terroristic threat and also increasing requirements from clients side force structures owners to continuous modernizations for audience safety and comfort improvement.

In Poland the biggest of this type sport structure began its activity in July 1956. It is located in Provincial Culture and Rest Park in Chorzow. At the opening day at grand stands were sitting above ninety thousands of fans and turnout record was written down in September 1963 during match of Górnik Zabrze with Austria Wiedeń, where for sport spectacle arrived above 120 thousands of fans. This audience number never repeated again and following modernisation changes significantly limited the number of fans taking part in events.

\footnotetext{
${ }^{1}$ Czestochowa University of Technology, aulfik@gmail.com;

${ }^{2}$ Czestochowa University of Technology, nowakstef@gmail.com;
} 


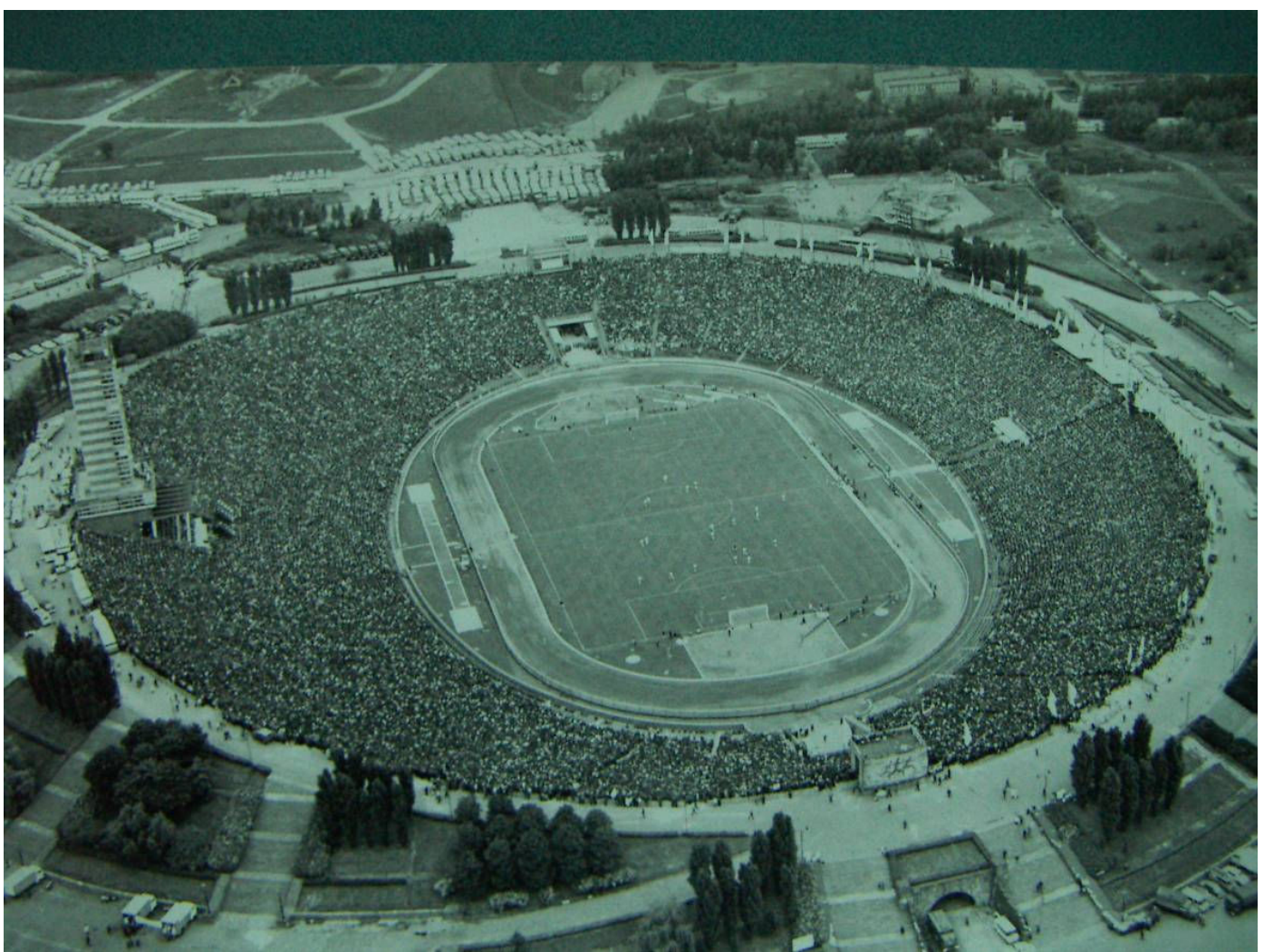

Fig. no. 1 - Silesia Stadium in 1973

Source: Silesia Stadium proximation materials

In nineties the structure was rebuilt. Infrastructure change was forced by tightened norms both in safety as well as in Football Federation range. Modernization included mainly east grand stand where through embankment liquidation were built two-level stands meeting safety standards and on their back were located modern changing rooms, training halls, conference halls and also remaining infrastructure essential for modern structure functioning. Whole was directly joined also with Silesian Stadium Hotel and restaurant assuring service complexity.

Currently National Stadium in Chorzów administers 47202 gross places at audience in range of sport events organization with use of main plate as arena. Theses number can get increased in case of realization of other events such as organized concerts, where after grass securing, playing field together with speedway track can be also used by organizers for standing places needs for spectacle participants. In such case the number of people on plate can be to 32.000 but it has to be in accordance with requirements resulting from decision given by Chorzów City President. Regardless of the mass event [ Law of 22nd August 1997 about mass events safety (Journal of Laws No. 106, position 680 with changes)] such decision is preceded by opinions of police, fire brigade, ambulance service and sanitary and epidemiological station. 


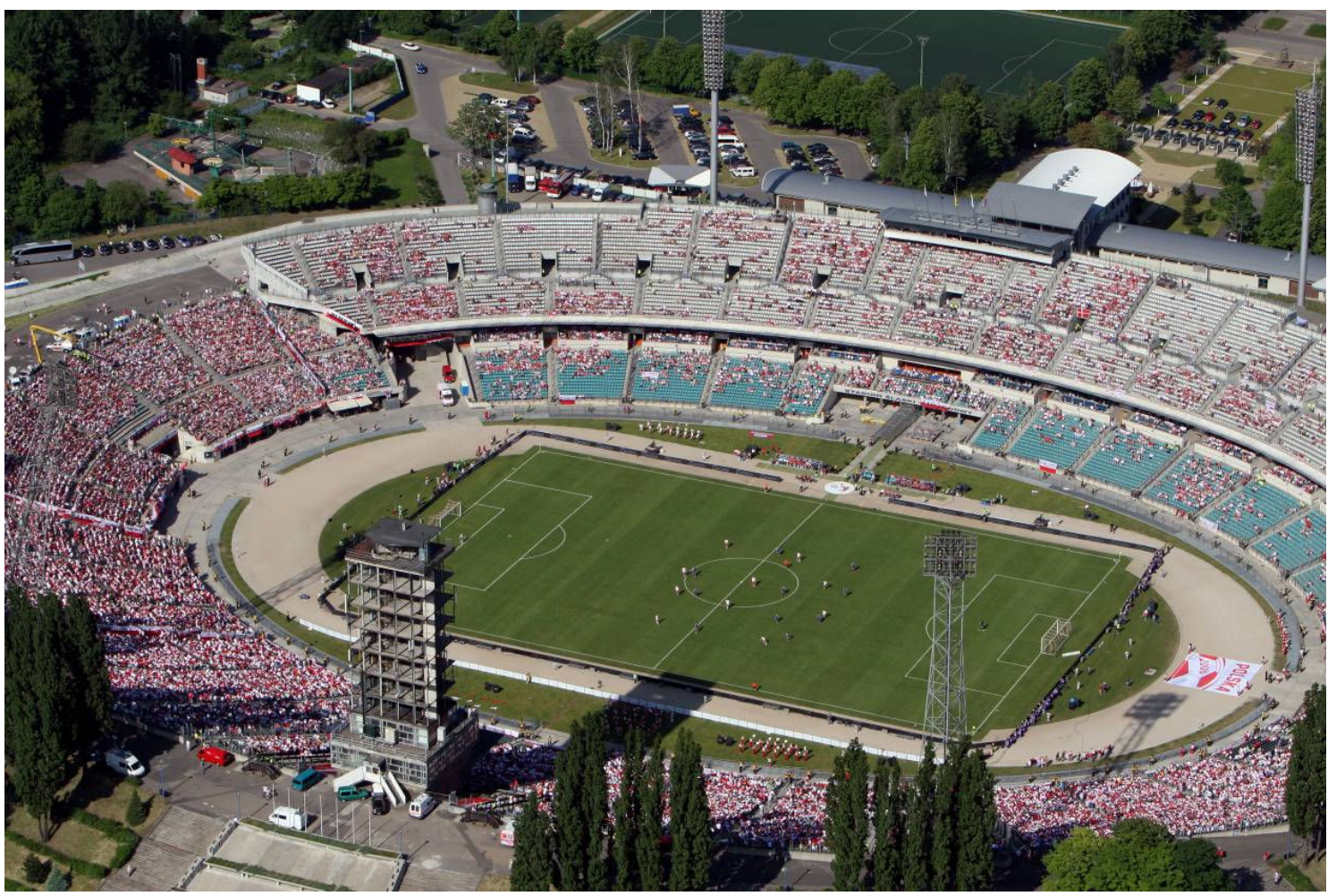

Fig. no. 2. - Silesia Stadium in 2008

Source: Silesia Stadium promotion materials

Among European stadiums on particular attention deserves Arena AufSchalke structure, which is one of objects where took place world championship matches in Germany. This is the most modern stadium in Europe, situated in Gelsenkirchen. Works during building modern stadium started since 1999. Total cost of its building was 186 Euro millions. Structure opening was on $13^{\text {th }}$ August 2001. [ Die Welt zu Gast auf Schalke - Gelsenkirchen, Pressestelle FIFA WM Stadt 2006, page 11]

Stadium can house, depending on event type from 53.000 to 78.000 audience. It is one of the most modern structures of this type in Europe and even on the world. 


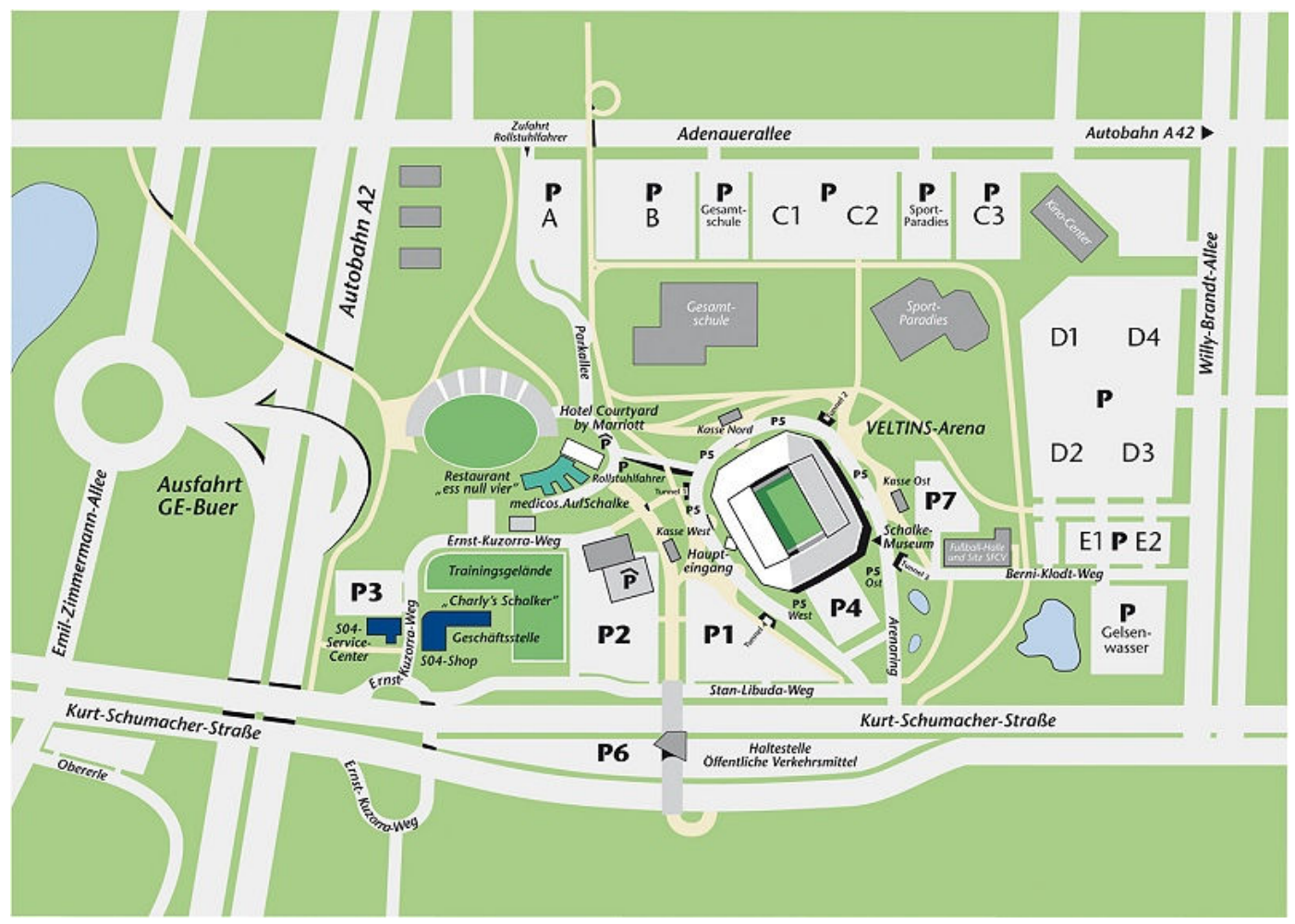

Fig. no. 3. - Plan of FC Schalke structures

Source: http://www.veltins-arena.de/besucher_anreise.php

Well thought out technical construction and infrastructure planning in early project stages and also developed procedures for safety assurance cause that organization of sport spectacles for ten thousands of audience does not present bigger organizational problems and causes that sport event proceeds without disturbances and next this can limit to minimum arisen dangerous situations or efficiently help to counteract them.

Sport together with its derivatives: structures, infrastructure - can be one of the components of composed marketing strategies and also element of region promotion. Prefect example is there football. In Europe, South America football stirs up enormous interest and emotions. This game also becomes more and more popular in Asia, Australia and also North America. Potential which lies in football picture FIFA 2006 World Championships. Owing to this event significantly increased interest in Germany where still long after ending tournament tourists would visit sport structures. At present time these issues are particularly important for Poland and Ukraine countries in which are going to take place football games in the confines of EURO 2012. Appropriate preparation of infrastructure, both sport as well also other like hotel transport base, would bear fruits not only with order during EURO organisation but also in significant degree would cause Polish touristic base more attractive. And this next would bring through following years measurable financial profits for activated regions.

Identification of main threats and also stress causing situations during realisation of big sport events on example of football matches

Sport spectacle organizer is responsible for participants safety. During event realisation the most dangerous moments of its organization is control of people getting in stadium terrain, break during match and also event final stage, where huge number of audience at one time lives terrain. Obviously safety during match is also important and even at this time happen incidents in form of pseudo-fans fights but more often brawls break out before or after match. In cases when before match order services expect that there can happen clashes between fans there are undertaken 
additional securing actions in escort form during way of visiting groups of fans through guarding companies supported with squad of riot police.

Used solutions during getting in audience on stadium terrain in order to secure safety mainly consist of two stages. First stage is tickets control and also participants graphical registration through monitoring system. Next there is carried out control preventing from carrying in dangerous subjects. These actions besides checking and punching ticket are essential elements during letting in on most of spectacles, however, significantly lengthen time necessary for filling up stadium stands.

So legitimate is possibilities analysis of optimal solution which would increase entrances capacity with simultaneous minimal probability of getting through to the spectacle undesirable people and risk of getting in dangerous subjects.

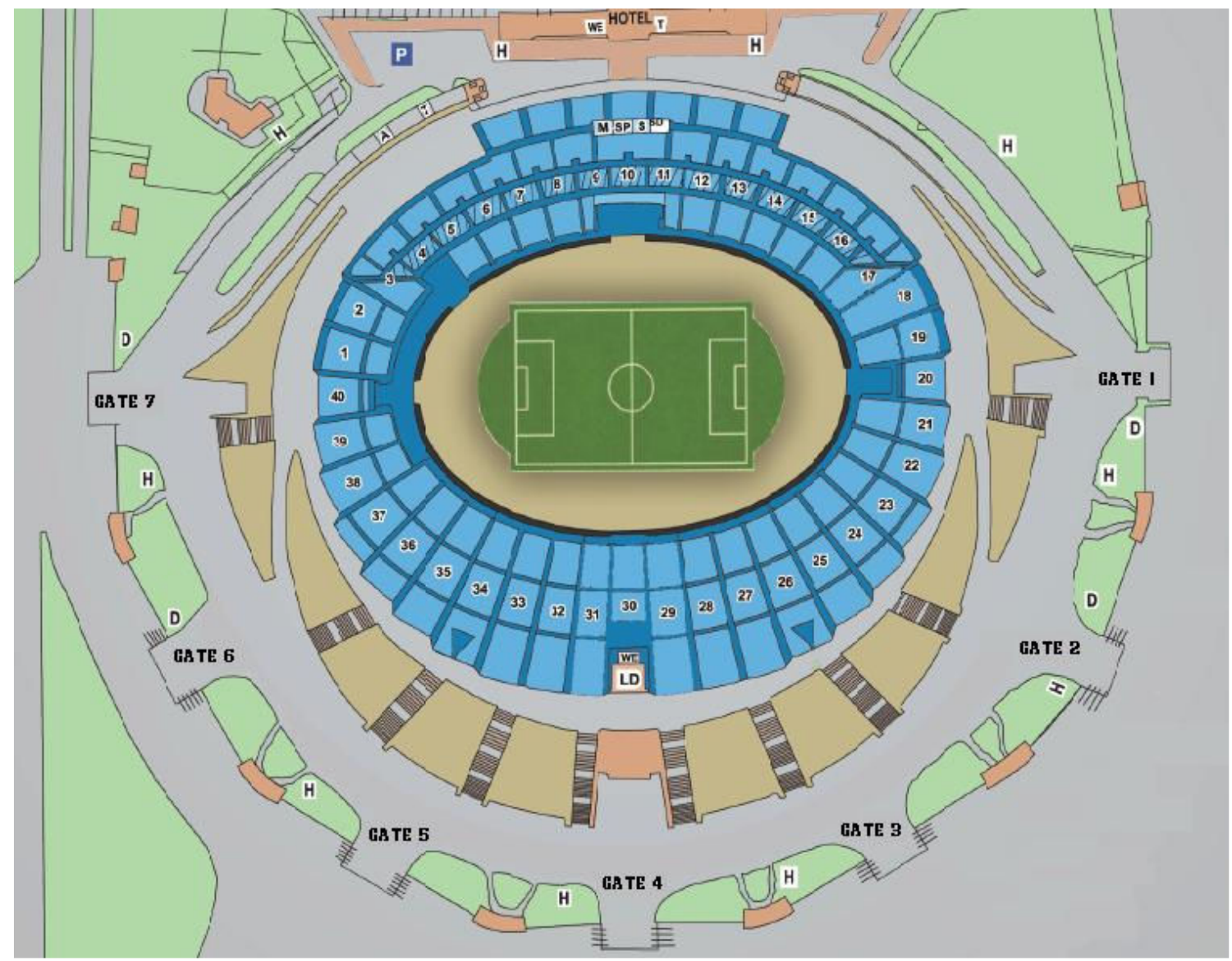

Fig. no. 4. - Silesia Stadium scheme together with communication system Source: Silesia Stadium information materials

Entrance on structure of Silesia Stadium terrain for fans can take place through seven main gates (figure 4), near which on opposite sides are located four gates, which arrangement is introduced at figure number 5. So maximally there can be activated 56 single gates. Entrances organisation depend on tickets control, their punching, initial control of carried in subjects and also participants registration through cameras system, in which direction entering people are obliged to look during filling up the stadium. Cameras systems register all event participants and in case of occurring dangerous situation are valuable information source about spectacle participants for order services. These actions are carried out by one control person marked at figure with four-arms star with number one. After finishing this stage fans are directed to guards marked at figure 5 as stars with numbers 2, 3 and 4 for precise control which should prevent from carrying in any dangerous 
subjects. At this stage there can also be eliminated trial of carrying in on stadium terrain pyrotechnical materials and prevent from terroristic attack.

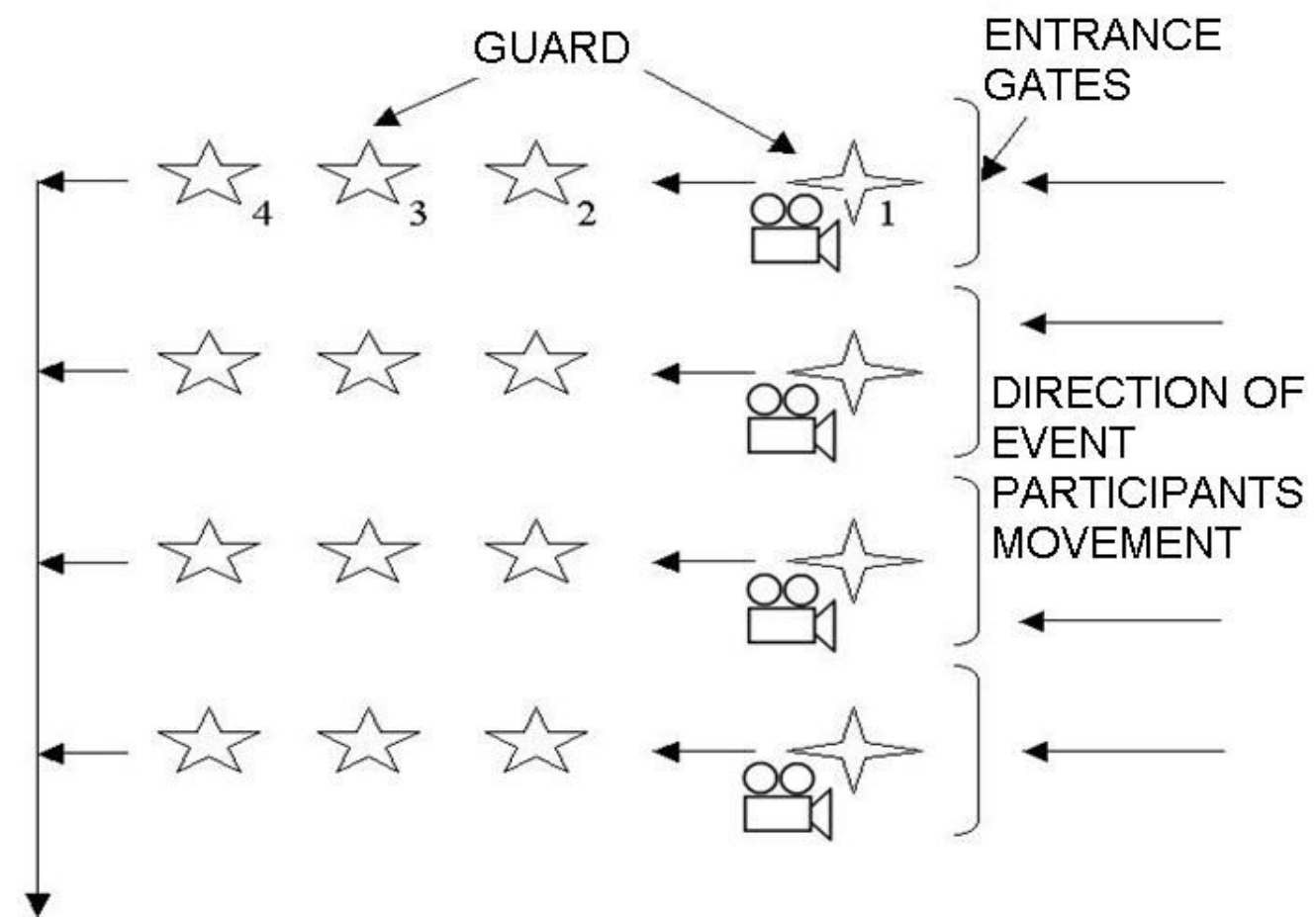

Fig. no. 5. - Organization scheme of one entrance on sport event area Source: Own study

At this stage of sport event organisation the most often occurs aggression increase among people who wants to get in the stadium and have to wait in long queues and also stress among guards workers. Precise revision of people entering increases safety inside stadium but significantly lengthens time spent in queues before entrance.

Carried out research on between-countries matches indicated that maximal number of fans getting in with appropriate keeping safety standards is between 35 and 38 people going through one gate for each 5 minutes. So when assuming that maximal usage of all 56 gates in one hour there can be safely brought at stadium about 25000 audience. This amount can be additionally increased with changed control system or with increased guards number on entrance.

Huge problem on European stadiums are groups of fans who often stir up riots. Football federations from some time try to eliminate aggressive fans through limiting them entrance possibilities on object terrain, however, bandits problem during football games is still very present. One way of fighting with hooligans is also placing on particular sport clubs severe penalties, including closing stadiums or games realisation without fans participation. Such solution causes that clubs are interested in catching particularly aggressive viewers and imposing on them entry ban on stadium. 


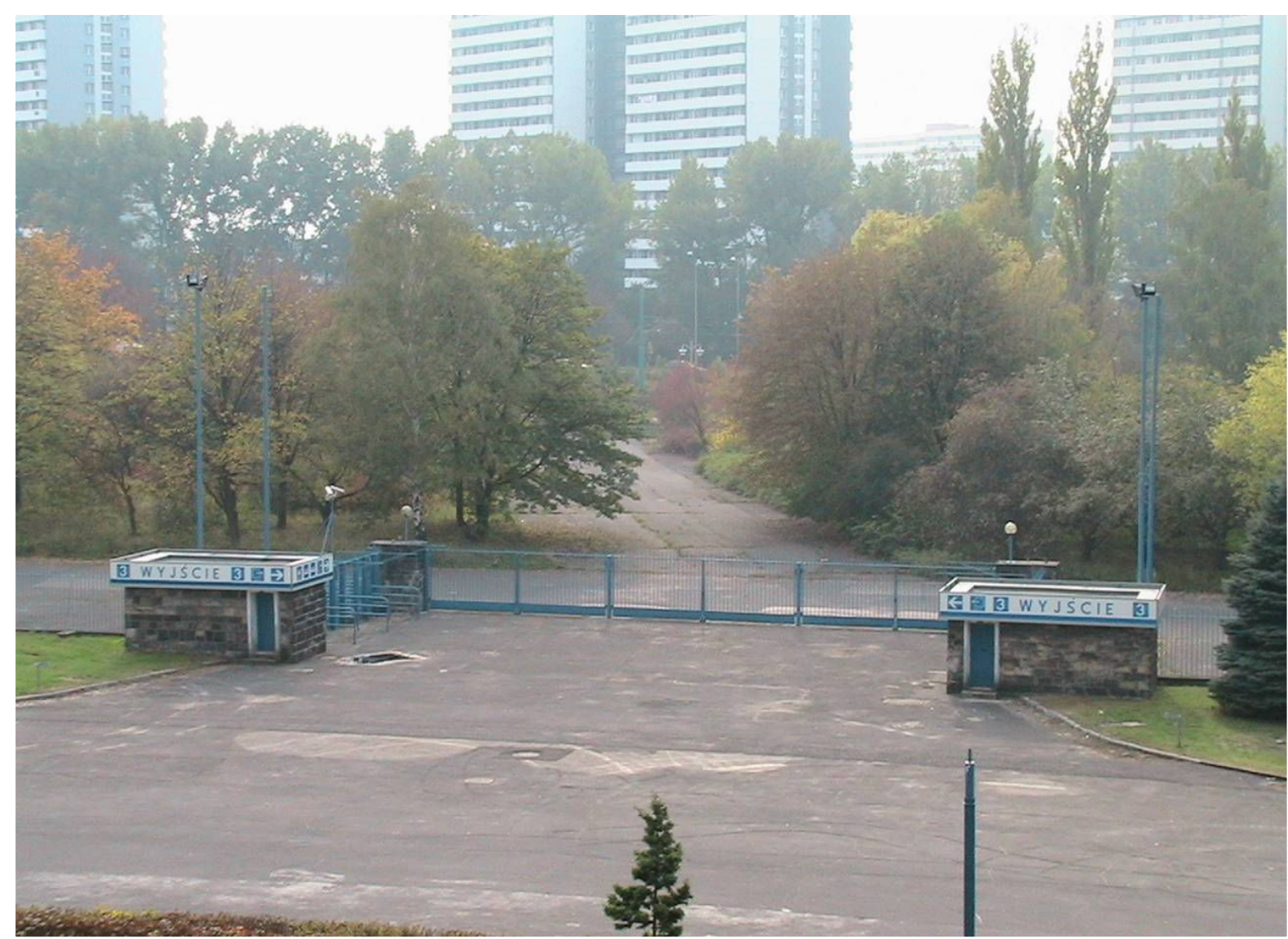

Fig. no. 6. - One of Silesia Stadium entrance gate

Source: Silesia Stadium promotion materials

However, for safety improvement at stadiums there are necessary thorough legal changes. Sport activists together with police organs think that introduction of stadium crime definition and also tightening penalties for assault on policeman during match significantly would improve safety. Project with such changes have been already filed to sport minister. After these changes it would be possible to fully use already existing monitoring system and after accurate films analysis after match to catch even the smallest offences and place before guilty accusations which would eliminate them as audience from next games. At present there are carried out works on introducing special cards - identity cards for fans, who do not pose any threat, without who it would not be possible to enter on stadium terrain.

There exist several ways to avoid or moderate conflict situations on stadiums. During sport games often fans behaviours are very emotional, what can lead aggression break out and control lost at stadium. So when organizing this type of event there should be placed particular attention on adequate placing audience in sectors already at tickets reservation stage; that is that fans of two different teams would not sit in the same sector. There also can be, only if there exists such technical possibility, to bring fans at stadium with separate entrances and at stadium stands to form additionally selected buffer zone in order to prevent even small clashes which could end with losing control on audience. One way of relieving emotions and eliminating stress situations is also friendly attitude to fans and not demonstrating force. In such way was secured safety in 2004 in Portugal.

\section{Conclusions}

Big sport and cultural events organization brings obligation of adopting responsibility through organizers for safety of many thousands of people. Correct projecting of all elements of 
spectacle organization and their efficient realisation would cause that spectacle would take place without any disturbances, stress and dangerous situations could be in simple way brought under control. Carried out researches on terrain of Polish stadiums head towards working out procedures which would be practically used during organization of European Championships in Football which are going to take place in Poland and Ukraine in 2012. Introduction of improved, effective procedures increasing audience safety is necessary also for the sake of higher threat from terroristic attacks side, which currently are main European Union threat.

\section{References:}

1. J. Klisiński, 2000, Profesjonalizacja i profesjonaliści w zarządzaniu sportem, Wydawnictwo Politechniki Częstochowskiej, Częstochowa;

2. H. Bieniok, 2001, Podstawy zarządzania przedsiębiorstwem, Wydawnictwo Akademii Ekonomicznej im. Karola Adamieckiego, Katowice;

3. S. Toczek-Werner, 2002, Podstawy rekreacji i turystyki, Wyd. AWF Wrocław;

4. A. Izydorczyk, 2003, Marketing w systemie kultury fizycznej, Polska Korporacja Menadżerów Sportu, Warszawa;

5. P. Suski; Zgromadzenia i imprezy masowe, LEXIS NEXIS 2007. 